\title{
Effect of the composition of biomass on the quality of syngas produced from thermochemical conversion based on thermochemical data prediction
}

Dai, Bingye; Zhu, Weiwei; Mu, Liwen; Guo, Xiaojing; Qian, Hongliang; Liang, Xiaodong; Kontogeorgis, Georgios M.

Published in:

Energy and Fuels

Link to article, DOI:

10.1021/acs.energyfuels.9b00106

Publication date:

2019

Document Version

Peer reviewed version

Link back to DTU Orbit

Citation (APA):

Dai, B., Zhu, W., Mu, L., Guo, X., Qian, H., Liang, X., \& Kontogeorgis, G. M. (2019). Effect of the composition of biomass on the quality of syngas produced from thermochemical conversion based on thermochemical data prediction. Energy and Fuels, 33(6), 5253-5262. https://doi.org/10.1021/acs.energyfuels.9b00106

\section{General rights}

Copyright and moral rights for the publications made accessible in the public portal are retained by the authors and/or other copyright owners and it is a condition of accessing publications that users recognise and abide by the legal requirements associated with these rights.

- Users may download and print one copy of any publication from the public portal for the purpose of private study or research.

- You may not further distribute the material or use it for any profit-making activity or commercial gain

- You may freely distribute the URL identifying the publication in the public portal 


\section{energy fuels: vounar}

Subscriber access provided by DTU Library

Biofuels and Biomass

Effect of the composition of biomass on the quality of syngas produced from thermochemical conversion based on thermochemical data prediction

Bingye Dai, Weiwei Zhu, Liwen Mu, Xiaojing Guo, Hongliang

Qian, Xiaodong Liang, and Georgios M. Kontogeorgis

Energy Fuels, Just Accepted Manuscript • DOI: 10.1021/acs.energyfuels.9b00106 • Publication Date (Web): 16 May 2019

Downloaded from http://pubs.acs.org on May 16, 2019

\section{Just Accepted}

"Just Accepted" manuscripts have been peer-reviewed and accepted for publication. They are posted online prior to technical editing, formatting for publication and author proofing. The American Chemical Society provides "Just Accepted" as a service to the research community to expedite the dissemination of scientific material as soon as possible after acceptance. "Just Accepted" manuscripts appear in full in PDF format accompanied by an HTML abstract. "Just Accepted" manuscripts have been fully peer reviewed, but should not be considered the official version of record. They are citable by the Digital Object Identifier (DOI®). "Just Accepted" is an optional service offered to authors. Therefore, the "Just Accepted" Web site may not include all articles that will be published in the journal. After a manuscript is technically edited and formatted, it will be removed from the "Just Accepted" Web site and published as an ASAP article. Note that technical editing may introduce minor changes to the manuscript text and/or graphics which could affect content, and all legal disclaimers and ethical guidelines that apply to the journal pertain. ACS cannot be held responsible for errors or consequences arising from the use of information contained in these "Just Accepted" manuscripts. 


\title{
Effect of the composition of biomass on the quality of syngas
}

\section{produced from thermochemical conversion based on thermochemical data prediction}

\author{
Bingye Dai a , Weiwei Zhu ${ }^{\mathrm{b}}$, Liwen $\mathrm{Mu}^{\mathrm{c}}$, Xiaojing Guo ${ }^{\mathrm{d}^{*}}$, Hongliang Qian ${ }^{\mathrm{b}}$, Xiaodong Liang ${ }^{\mathrm{e}}$, \\ Georgios M. Kontogeorgis e \\ a China Rural Technology Development Center, Beijing 100862, China; \\ b Department of Pharmaceutical Engineering, China Pharmaceutical University, Nanjing 210009, \\ China; \\ c Division of Machine Elements, Luleå University of Technology, Luleå, 97187, Sweden; \\ d The Education Ministry Key Laboratory of Resource Chemistry, Shanghai Key Laboratory of Rare \\ Earth Functional Materials and Department of Chemistry and Chemical Engineering, Shanghai Normal \\ University, Shanghai 200234, China; \\ e Department of Chemical and Biochemical Engineering, Technical University of Denmark, DK-2800 \\ Kgs. Lyngby, Denmark
}

\begin{abstract}
Syngas produced from thermochemical conversion of biomass has been paid more attention due to it can be converted to a variety of fuels and chemicals as substitutes for petroleum-based chemicals via Fischer-Tropsch process. In this study, one wheat straw and its element contents fluctuation in the feasible range are selected as samples firstly to study the effect of the biomass composition on the quality of syngas produced. Then, the thermochemical data (standard molar enthalpy of formation, standard molar entropy and heat capacity) of samples are predicted by high accurate prediction models. Thermochemical conversions of the samples are simulated by the Gibbs energy minimization method based on the results of thermochemical data prediction. At last, the effect of the biomass composition on the resource index (the amount of $\mathrm{CO}, \mathrm{H}_{2}$, the ratio of $\mathrm{H}_{2}$ to $\mathrm{CO}$ ) and energy index (lower heat value) of syngas is calculated and analyzed. This study provides a method to obtain the relationship between the composition of biomass and the quality of syngas produced.
\end{abstract}

KEYWORDS: Thermochemical conversion, Gibbs energy minimization, Composition effect, Syngas, Biomass

\section{INTRODUCTION}

Greenhouse gas emissions from anthropogenic activities such as the burning of fossil fuels for power generation are major contributors to the climate change. This necessitates a switch from conventional 
to renewable power sources such as solar photovoltaic, wind, biomass and hydroelectric generation ${ }^{1}$. Amongst the renewable energies, one of the most important energy sources in near future is biomass. With the exception of coal and oil, the third among the primary energy sources is the biomass ${ }^{2}$. Particularly, biomass energy is a $\mathrm{CO}_{2}$-zero energy that does not interfere with the global carbon itself ${ }^{3}$. Biomass resources include wood and wood wastes, agricultural crops and their waste byproducts, municipal solid waste, animal wastes, waste from food processing and aquatic plants and algae. Biomass can be exploited directly or through thermochemical or biochemical processes to obtain electrical, thermal or chemical energy. Thermochemical conversion processes include three basis subcategories: combustion, pyrolysis and gasification ${ }^{4}$. Pyrolysis is a process of producing gas, oil and solid from biomass under high temperature in the absence of air or steam. The conventional gasification technology can be defined as the partial combustion of biomass by controlling the amount of air to transform hydrocarbons into carbon monoxide, carbon dioxide and hydrogen. Compared with biochemical conversion, the main advantage of thermochemical conversion is that the lignin in biomass can be converted. The main gas products of the pyrolysis and gasification under high temperature are syngas (carbon monoxide and hydrogen), which can be converted to a variety of fuels $\left(\mathrm{H}_{2}\right.$, Fischer-Tropsch diesels, synthetic gasoline) and chemicals (methanol, urea) as substitutes for petroleum-based chemicals. More importantly, the products are compatible with existing petroleum refining operations ${ }^{5}$.

The composition of the syngas produced at thermochemical equilibrium can be estimated using different approaches: kinetic/dynamic models ${ }^{6}$, artificial neural networks models ${ }^{7}$, and equilibrium models ${ }^{8}$. The Gibbs energy minimization method is one of the equilibrium models, whose key advantage is its widely application owing to predictive capability without requiring an extended set of data to train the model compared to kinetic/dynamic models and that it does not necessitate the selection of appropriate chemical reactions allowing the formation of products compared to direct chemical equilibrium computation ${ }^{9,10}$. Due to the complex composition of biomass itself and its complex reaction pathways in the pyrolysis and gasification process, the Gibbs energy minimization method is used in the pyrolysis and gasification of different types of biomass in this study.

There are a lot of articles that simulate the pyrolysis and gasification process of biomass through the Gibbs energy minimization method ${ }^{11-17}$. Most of their attentions are focused on the operating condition such as temperature ${ }^{11,13-18}$, equivalence ratio ${ }^{11-15}$ and moisture ${ }^{12,15,16}$ on the gas products. From the 
proximate analysis or ultimate analysis of biomass, the composition of biomasses varies depending on the types of biomass considered and even for the same types of biomass they may vary at different regions and seasons. Therefore, it is still a challenge to study the effect of the composition of biomass on the gas products from the pyrolysis and gasification processes for the composition of different biomass varies.

The aim of this paper is to study the effect of different biomass composition on the quality of syngas produced from pyrolysis and gasification process. Although biomass is composed of cellulose, hemicellulose and lignin, the composition of biomass is represented by elements instead of actual substances (cellulose, hemicellulose and lignin) for their contents cannot be quantified accurately. In our previous studies 19-22, the relationship between elemental contents of biomass and their thermochemical data was verified and high prediction models were established. Therefore, the composition of biomass can be represented by their elemental contents in thermochemical conversion calculation of biomass. Process simulations are performed on the corresponding processes to obtain the relationship between different types of biomass feedstocks and their gas products based on thermochemical data prediction. The innovation of this study are related to the following two points: 1) Focus on the effect of the composition (elemental contents) of biomass on the quality of syngas; 2) The experimental thermochemical data of biomass are unknown when the single factor of $\mathrm{C}, \mathrm{H}$ or $\mathrm{O}$ content fluctuates up and down, thermochemical conversions of biomass are simulated by the Gibbs energy minimization method based on thermochemical data prediction.

\section{MATERIAL AND METHODS}

\subsection{Gibbs energy minimization method}

The total Gibbs energy of the system is expressed as follows ${ }^{23,24}$ :

$$
G_{T, p}^{t}=g\left(n_{1}, n_{2}, n_{3}, \ldots, n_{i}, \ldots, n_{w}\right) \quad(i=1,2,3, \ldots, w)
$$

where $G_{T, p}^{t}$ is the total Gibbs energy of the system and $n_{i}$ is referred to molar mass of each species (mol). The objective is to find the set of $n_{i}$ for which the total Gibbs energy of system is minimized. The material balance of every elements present in the system is given by

$$
\sum_{i} n_{i} a_{i k}=A_{k}
$$


where $a_{i k}$ is the number of atoms of the $k$ th element present in each molecule of the chemical species $i$, $A_{k}$ is the total number of atomic masses of the $k$ th element in the system.

The Gibbs energy of the system is minimized with the Lagrange method by using the elemental mass balances as subsidiary constraints. Therefore, a new function is derived by adding Eqs. (1) and (2),

$$
F=G_{T, p}^{t}+\sum_{k} \lambda_{k}\left(\sum_{i} n_{i} a_{i k}-A_{k}\right)
$$

where $\lambda_{k}$ are the Lagrange multipliers. The minimum value of $F$ is occurred when its partial derivative with respect to each species equal to zero at specified temperature and pressure,

$$
\frac{\partial F}{\partial n_{i}}=\frac{\partial G_{T, p}^{t}}{\partial n_{i}}+\sum_{k} \lambda_{k} a_{i k}=0
$$

where $\frac{\partial G_{T, p}^{t}}{\partial n_{i}}$ is known as chemical potential $\left(\mu_{i}\right)$, therefore, the following equation can be obtained.

$$
\mu_{i}+\sum_{k} \lambda_{k} a_{i k}=0
$$

The chemical potential is defined as 23,24 ,

$$
\begin{aligned}
& \mu_{i}=\Delta_{\mathrm{f}} G_{\mathrm{m}, i}+\mathrm{R} T \ln \left(\frac{n_{i}}{n_{\text {total }}}\right)=\Delta_{\mathrm{f}} H_{\mathrm{m}, i}+T S_{\mathrm{m}, i}+\mathrm{R} T \ln \left(\frac{n_{i}}{n_{\text {total }}}\right) \\
& =\Delta_{\mathrm{f}} H_{\mathrm{m}, i}^{o}+\int_{298.15}^{T} c_{p i} \mathrm{~d} T+T\left(S_{\mathrm{m}, i}^{o}+\int_{298.15}^{T} \frac{c_{p i}}{T} \mathrm{~d} T\right)+\mathrm{R} T \ln \left(\frac{n_{i}}{n_{\text {total }}}\right)
\end{aligned}
$$

where $\Delta_{\mathrm{f}} H_{\mathrm{m}, i}^{o}, \quad S_{\mathrm{m}, i}^{o}, \quad c_{p i}, \mathrm{R}$ are the standard molar enthalpy of formation, the standard molar entropy, heat capacity, and the universal gas constant respectively. $n_{\text {total }}$ means the total mole of all species $i$.

Putting Eq. (6) in Eq. (5) gives,

$$
\Delta_{\mathrm{f}} H_{\mathrm{m}, i}^{o}+\int_{298.15}^{T} c_{p, i} \mathrm{~d} T+T\left(S_{\mathrm{m}, i}^{o}+\int_{298.15}^{T} \frac{c_{p, i}}{T} \mathrm{~d} T\right)+\mathrm{R} T \ln \left(\frac{n_{i}}{n_{\text {total }}}\right)+\sum_{k} \lambda_{k} a_{i k}=0 \quad(i=1,2,3, \ldots, w)
$$

The above equation represents $w$ equilibrium equations referring to each species present in the system. As a result of the calculation by Eq. (7), the equilibrium composition $n_{i}$ (such as $n_{\mathrm{H} 2}$ and $n_{\mathrm{CO}}$ obtained from pyrolysis and oxygen gasification in this study) of the multi-phase system at given temperature is obtained.

\subsection{Estimating thermochemical data of dry biomass}


According to Eq. (4), the values of standard molar enthalpy of formation $\left(\Delta_{\mathrm{f}} H_{\mathrm{m}}^{o}\right)$, standard molar entropy $\left(S_{\mathrm{m}}^{o}\right)$ and heat capacity $\left(c_{p}\right)$ are necessary to the calculation by the Gibbs energy minimization method.

\subsubsection{Estimating standard molar enthalpy of formation $\left(\Delta_{\mathrm{f}} H_{\mathrm{m}}^{o}\right)$}

The combustion reaction between dry biomass and oxygen in oxygen bomb calorimeter is described by:

$$
\mathrm{C}_{x} \mathrm{H}_{y} \mathrm{O}_{z} \mathrm{~N}_{a} \mathrm{~S}_{b}+\left(x+\frac{y}{4}-\frac{z}{2}+b\right) \mathrm{O}_{2}(g) \rightarrow x \mathrm{CO}_{2}(g)+\frac{y}{2} \mathrm{H}_{2} \mathrm{O}(l)+\frac{a}{2} \mathrm{~N}_{2}(g)+b \mathrm{SO}_{2}(g)
$$

where $x, y, z, a, b$ are respectively the moles of carbon $(\mathrm{C})$, hydrogen $(\mathrm{H})$, oxygen $(\mathrm{O})$, nitrogen $(\mathrm{N})$ and sulfur (S) in $100 \mathrm{~g}$ of dry biomass. $x=\mathrm{C} / 12, y=\mathrm{H}, z=\mathrm{O} / 16, a=\mathrm{N} / 14$, and $b=\mathrm{S} / 32$ for unit conversion. $\mathrm{C}$, $\mathrm{H}, \mathrm{N}, \mathrm{S}$ are determined by ultimate analysis (wt $\%$, dry biomass), and the $\mathrm{O}$ content usually serves as an indicator to differentiate the sum of the percentages of $\mathrm{C}, \mathrm{H}, \mathrm{N}, \mathrm{S}$ and that of the ash $(\mathrm{O}=$ 100-C-H-N-S-Ash).

The value of energy change of combustion reaction in oxygen bomb calorimeter is higher heat value (HHV, $\mathrm{kJ} \cdot \mathrm{kg}^{-1}$, based on dry biomass), then,

$$
\begin{aligned}
& -0.001 M \times H H V=x \Delta_{\mathrm{f}} H_{\mathrm{m}, \mathrm{CO} 2}^{o}+\frac{y}{2} \Delta_{\mathrm{f}} H_{\mathrm{m}, \mathrm{H} 2 \mathrm{O}(\mathrm{l})}^{o}+\frac{a}{2} \Delta_{\mathrm{f}} H_{\mathrm{m}, \mathrm{N} 2}^{o}+b \Delta_{\mathrm{f}} H_{\mathrm{m}, \mathrm{SO2}}^{o} \\
& -\Delta_{\mathrm{f}} H_{\mathrm{m}, \mathrm{CHH} \mathrm{O} \mathrm{ONaSb}}^{o}-\left(x+\frac{y}{4}-\frac{z}{2}+b\right) \Delta_{\mathrm{f}} H_{\mathrm{m}, 02}^{o}
\end{aligned}
$$

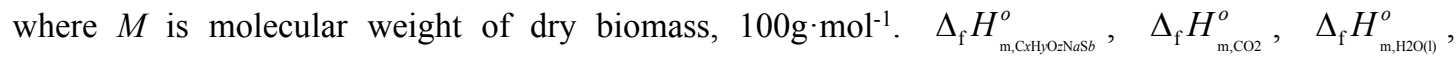
$\Delta_{\mathrm{f}} H_{\mathrm{m}, \mathrm{N} 2}^{o}, \quad \Delta_{\mathrm{f}} H_{\mathrm{m}, \mathrm{OO2}}^{o}$ and $\Delta_{\mathrm{f}} H_{\mathrm{m}, \mathrm{O} 2}^{o}$ are standard molar enthalpy of formation of dry biomass, carbon dioxide, liquid water, nitrogen, sulfur dioxide and oxygen, then,

$$
\begin{aligned}
& \Delta_{\mathrm{f}} H_{\mathrm{m}, \mathrm{CH} H \mathrm{O} \mathrm{ON} a \mathrm{~S} b}^{o}=x \Delta_{\mathrm{f}} H_{\mathrm{m}, \mathrm{CO2}}^{o}+\frac{y}{2} \Delta_{\mathrm{f}} H_{\mathrm{m}, \mathrm{H} 2 \mathrm{O}(\mathrm{l})}^{o}+\frac{a}{2} \Delta_{\mathrm{f}} H_{\mathrm{m}, \mathrm{N} 2}^{o}+b \Delta_{\mathrm{f}} H_{\mathrm{m}, \mathrm{SO2}}^{o} \\
& -\left(x+\frac{y}{4}-\frac{z}{2}+b\right) \Delta_{\mathrm{f}} H_{\mathrm{m}, 02}^{o}+0.001 M \times H H V
\end{aligned}
$$

where $\Delta_{\mathrm{f}} H_{\mathrm{m}, \mathrm{CO2}}^{o}, \Delta_{\mathrm{f}} H_{\mathrm{m}, \mathrm{H} 20(\mathrm{l})}^{o}, \Delta_{\mathrm{f}} H_{\mathrm{m}, \mathrm{N} 2}^{o}, \Delta_{\mathrm{f}} H_{\mathrm{m}, \mathrm{SO2}}^{o}$ and $\Delta_{\mathrm{f}} H_{\mathrm{m}, \mathrm{O2}}^{o}$ can be looked up from data handbook 25, and their values are listed in Table $1 . H H V$ can be given by experimental data or prediction model. For the types and composition of biomasses varied, $H H V$ is estimated by the high accurate model proposed from our previous study ${ }^{20}$ and the equation is listed as follows.

$$
H H V=874.08\left(\frac{1}{3} \mathrm{C}+\mathrm{H}\right) \quad \mathrm{kJ} \cdot \mathrm{kg}^{-1}
$$


Table 1 Thermochemical data of substances involved in the calculation of biomass's enthalpy

\begin{tabular}{|c|c|c|c|c|c|}
\hline Substance & $\mathrm{CO}_{2}$ & $\mathrm{H}_{2} \mathrm{O}$ & $\mathrm{N}_{2}$ & $\mathrm{SO}_{2}$ & $\mathrm{O}_{2}$ \\
\hline$\Delta_{\mathrm{f}} H_{\mathrm{m}, i} / \mathrm{kJ} \mathrm{mol}^{-1}$ & -393.505 & -285.830 & 0 & -296.813 & 0 \\
\hline \multicolumn{6}{|c|}{$\begin{aligned} \Delta_{\mathrm{f}} H_{\mathrm{m}, \mathrm{C} \text { KH } \mathrm{O} \text { INaSb }}^{o} & =-393.505 x-142.915 y-296.813 b+M \times 0.001 \times 874.08\left(\frac{1}{3}\right. \\
& =-393.505 x-142.915 y-296.813 b+0.874 M \times\left(\frac{1}{3} \mathrm{C}+\mathrm{H}\right)\end{aligned}$} \\
\hline
\end{tabular}

According to the definition of $x, y$ and $b$, the final calculation equation of standard molar enthalpy of formation of dry biomass is

$$
\Delta_{\mathrm{f}} H_{\mathrm{m}, \mathrm{CH} H \mathrm{O} \mathrm{ONaSb}}^{o}=-32.762 \mathrm{C}-141.781 \mathrm{H}-9.258 \mathrm{~S}+87.4\left(\frac{1}{3} \mathrm{C}+\mathrm{H}\right) \quad \mathrm{kJ} \cdot \mathrm{mol}^{-1}
$$

\subsubsection{Estimating standard molar entropy $S_{m}^{o}$}

Song et al. ${ }^{26}$ developed a relationship between standard entropy and composition of 27 types of solid biomolecules and proposed the specific entropy of dry biomass as follows.

$$
s^{o}=0.0055 \mathrm{C}+0.0954 \mathrm{H}+0.0096 \mathrm{O}+0.0098 \mathrm{~N}+0.0138 \mathrm{~S} \quad \mathrm{~kJ} \cdot \mathrm{kg}^{-1} \cdot \mathrm{K}^{-1}
$$

In this study, the calculation is based on mole, and Eq. (13) can be expressed as:

$$
\begin{array}{rlr}
S_{m}^{o} & =M \times(0.0055 \mathrm{C}+0.0954 \mathrm{H}+0.0096 \mathrm{O}+0.0098 \mathrm{~N}+0.0138 \mathrm{~S}) \\
& =100 \times(0.0055 \mathrm{C}+0.0954 \mathrm{H}+0.0096 \mathrm{O}+0.0098 \mathrm{~N}+0.0138 \mathrm{~S}) \quad \mathrm{J} \cdot \mathrm{mol}^{-1} \cdot \mathrm{K}^{-1} \\
& =0.1 \times(0.0055 \mathrm{C}+0.0954 \mathrm{H}+0.0096 \mathrm{O}+0.0098 \mathrm{~N}+0.0138 \mathrm{~S}) \quad \mathrm{kJ} \cdot \mathrm{mol}^{-1} \cdot \mathrm{K}^{-1}
\end{array}
$$

\subsubsection{Estimating heat capacity $C_{\mathrm{p}}$}

Heat capacity of dry biomass and temperature showed a good linear relationship ${ }^{27}$ and the proposed specific heat capacity of dry biomass is

$$
c_{p}=1113.68+4.8567(T-273.15)=-212.928+4.8567 T \quad \mathrm{~J} \cdot \mathrm{kg}^{-1} \cdot \mathrm{K}^{-1}
$$

Then, Eq. (15) after unit conversion can be expressed as

$$
\begin{aligned}
C_{p} & =0.001 M c_{p}=0.1(-212.928+4.8567 T) \quad \mathrm{J} \cdot \mathrm{mol}^{-1} \cdot \mathrm{K}^{-1} \\
& =10^{-4}(-212.928+4.8567 T) \quad \mathrm{kJ} \cdot \mathrm{mol}^{-1} \cdot \mathrm{K}^{-1}
\end{aligned}
$$

\subsection{Definition of equivalence ratio}

Equivalence ratio $(E R)$ is defined as the ratio of the actual amount of oxygen to the stoichiometric amount during the gasification process ${ }^{28}$.

According to the reaction of biomass in the oxygen bomb calorimeter as described in section 2.1, the 
theoretical stoichiometric oxygen consumption of 1 mol biomass is $x+\frac{y}{4}-\frac{z}{2}+b$ mol, therefore, the definition of $E R$ is

$$
E R=\frac{\text { actual oxygen comsuption }}{x+\frac{y}{4}-\frac{z}{2}+b}
$$

\subsection{Evaluation of the quality of syngas}

Syngas is generally used as energy source to supply energy or resource source (as a chemical raw material) to synthesize other materials such as via Fischer-Tropsch process. Therefore, the quality of syngas is represented by energy index and resource index in this study. The energy index is expressed as the lower heat value (LHV) instead of HHV of syngas. The difference is that the LHV considers water in the products to be gas while the HHV considers water to be a liquid. Although water can indeed release heat from the gas phase to the liquid phase in the actual process, the energy level is too low to be used actually. The resource index is expressed according to the amount of $\mathrm{CO}$ and $\mathrm{H}_{2}$ in the syngas and the molar ratio of $\mathrm{H}_{2}$ to $\mathrm{CO}$, because the latter molar ratio can indicate $\mathrm{H} / \mathrm{C}$, which provides a basis for the Fischer-Tropsch synthesis.

The formula of calculating LHV of syngas in the study of Mohammed et.al ${ }^{29}$ is as follows:

$$
L H V=4.2\left(30.0 x_{\mathrm{CO}}+25.7 x_{\mathrm{H}_{2}}+85.4 x_{\mathrm{CH}_{4}}\right) \mathrm{kJ} \cdot \mathrm{m}^{-3}
$$

where $x_{\mathrm{CO}}, x_{\mathrm{H}_{2}}$ and $x_{\mathrm{CH}_{4}}$ are the molar ratio of $\mathrm{CO}, \mathrm{H}_{2}$ and $\mathrm{CH}_{4}$ in the gas products, respectively.

\subsection{Sample selected}

We analyzed the elemental composition of 78 types of biomass reviewed by Vassilev et al. ${ }^{30}$ and found that the $\mathrm{C}$ content ranges from 36.1 to 55.8 , the $\mathrm{H}$ content ranges from 2.94 to 9.77 , the $\mathrm{O}$ content ranges from 30.7 to 46.9 , the $\mathrm{N}$ content range is $0.1-3.1, \mathrm{~S}$ content range is $0.01-0.55$, and ash content range is $0.1-20.1$. Therefore, the average value of $\mathrm{C}$ content, $\mathrm{H}$ content and $\mathrm{O}$ content is 45.95 , 6.355 and 38.8 , respectively.

One wheat straw is selected because its element content is at the average level of the $\mathrm{C}$ content, $\mathrm{H}$ content and $\mathrm{O}$ content of the 78 types of biomass ${ }^{30}$, which allows the element contents to bear wider fluctuation range (within the elemental range of the 78 types of biomass), thus brings about better understanding of the effect of element contents on pyrolysis and gasification products. The 
composition of the wheat straw (denoted as sample I) is shown in Table 2.

Table 2 Composition of wheat straw (denoted as sample I)

\begin{tabular}{cccccccccc}
\hline \multirow{3}{*}{ Biomass } & \multicolumn{3}{c}{ Proximate analysis } & \multicolumn{3}{c}{ Ultimate analysis } & & Ref. \\
& VM & FC & Ash & C & H & O & N & S & \\
\hline Wheat straw & 74.8 & 18.1 & 7.1 & 45.9 & 5.67 & 40.5 & 0.7 & 0.16 & 30 \\
\hline
\end{tabular}

Based on sample I, in order to discuss the effect of $\mathrm{C}, \mathrm{H}, \mathrm{O}$ content of biomass on syngas produced from pyrolysis and gasification processes, each element content can be fluctuated within the range of $\mathrm{C}, \mathrm{H}, \mathrm{O}$ content of the 78 types of biomass, their composition is shown in Table 3. It should be noted that when the content of one element fluctuates, the content ratio of the other elements remains constant.

Table 3 Samples set for examining the individual effect of $\mathrm{C}, \mathrm{H}$, O element content

\begin{tabular}{|c|c|c|c|c|c|c|c|}
\hline Element & Samples & Ash & $\mathrm{C}$ & $\mathrm{H}$ & $\mathrm{O}$ & $\mathrm{N}$ & $\mathrm{S}$ \\
\hline $\mathrm{C}, \mathrm{H}, \mathrm{O}$ & $I$ & 7.1 & 45.9 & 5.67 & 40.5 & 0.7 & 0.16 \\
\hline \multirow{4}{*}{$\mathrm{C}$} & 1 & 8.412 & 35.9 & 6.718 & 47.986 & 0.829 & 0.19 \\
\hline & 2 & 7.756 & 40.9 & 6.194 & 44.243 & 0.765 & 0.175 \\
\hline & 3 & 6.444 & 50.9 & 5.146 & 36.757 & 0.635 & 0.145 \\
\hline & 4 & 5.788 & 55.9 & 4.622 & 33.014 & 0.571 & 0.13 \\
\hline \multirow{4}{*}{$\mathrm{H}$} & 5 & 7.326 & 47.36 & 2.67 & 41.788 & 0.722 & 0.165 \\
\hline & 6 & 7.213 & 46.63 & 4.17 & 41.144 & 0.711 & 0.163 \\
\hline & 7 & 6.949 & 44.927 & 7.67 & 39.641 & 0.685 & 0.157 \\
\hline & 8 & 6.799 & 43.954 & 9.67 & 38.783 & 0.67 & 0.153 \\
\hline \multirow{4}{*}{$\mathrm{O}$} & 9 & 8.293 & 53.614 & 6.623 & 30.5 & 0.818 & 0.187 \\
\hline & 10 & 7.697 & 49.757 & 6.146 & 35.5 & 0.759 & 0.173 \\
\hline & 11 & 6.742 & 43.586 & 5.384 & 43.5 & 0.665 & 0.152 \\
\hline & 12 & 6.384 & 41.271 & 5.098 & 46.5 & 0.629 & 0.144 \\
\hline
\end{tabular}




\subsection{Assumptions in process simulation}

The following assumptions have been made for facilitating the process simulation calculations via the Gibbs energy minimization method:

(1) The mass of biomass is taken as $100 \mathrm{~g}$ in all samples.

(2) For the simulation of thermochemical conversion processes with the Gibbs energy minimization method, char is represented by carbon and ash.

(3) All gaseous components are ideal gas.

\section{RESULTS AND DISCUSSION}

\subsection{Estimation of biomass thermochemical data}

The thermochemical data estimation results of the samples used to examine the influence of different contents of $\mathrm{C}, \mathrm{H}$ and $\mathrm{O}$ elements are listed in Table 4.

Table 4 Estimated results of thermochemical data for samples respectively affected by $\mathrm{C}, \mathrm{H}, \mathrm{O}$ element

content

\begin{tabular}{|c|c|c|c|c|}
\hline \multirow{2}{*}{ Element } & \multirow{2}{*}{ Samples } & \multirow{2}{*}{$\begin{array}{c}\text { Calculated HHV } \\
\qquad \mathrm{kJ} \cdot \mathrm{kg}^{-1}\end{array}$} & \multirow{2}{*}{$\begin{array}{c}\Delta_{\mathrm{f}} H_{\mathrm{m}}^{\mathrm{o}} \\
\mathrm{kJ} \cdot \mathrm{mol}^{-1}\end{array}$} & \multirow{2}{*}{$\begin{array}{c}S_{\mathrm{m}}^{\mathrm{o}} \\
\mathrm{J} \cdot \mathrm{mol}^{-1} \cdot \mathrm{K}^{-1}\end{array}$} \\
\hline & & & & \\
\hline $\mathrm{C}, \mathrm{H}, \mathrm{O}$ & $I$ & 18327.78 & -606.505 & 110.666 \\
\hline \multirow{4}{*}{$\mathrm{C}$} & 1 & 16330.45 & -634.737 & 119.958 \\
\hline & 2 & 17329.12 & -621.276 & 115.351 \\
\hline & 3 & 19326.45 & -590.422 & 105.903 \\
\hline & 4 & 20325.11 & -573.030 & 101.062 \\
\hline \multirow{4}{*}{$\mathrm{H}$} & 5 & 16131.06 & -436.751 & 85.790 \\
\hline & 6 & 17229.42 & -521.752 & 98.213 \\
\hline & 7 & 19792.26 & -719.122 & 127.316 \\
\hline & 8 & 21256.74 & -831.299 & 144.020 \\
\hline \multirow{4}{*}{$\mathrm{O}$} & 9 & 21408.08 & -733.984 & 112.808 \\
\hline & 10 & 19867.93 & -669.325 & 111.749 \\
\hline & 11 & 17403.69 & -569.694 & 110.005 \\
\hline & 12 & 16479.60 & -533.546 & 109.336 \\
\hline
\end{tabular}




\subsection{Model validation}

The accuracy of the Gibbs energy minimization method itself in the calculation of thermochemical equilibrium of biomass pyrolysis and gasification process is no problem according to literature. The reason of model validation in this study is to verify the accuracy of thermochemical equilibrium via the Gibbs energy minimization method based on our HHV prediction model ${ }^{20}$.

\subsubsection{Pyrolysis process}

Model in pyrolysis process is validated by the relationship between the products of pyrolysis process of wheat straw (sample I) and pyrolysis temperature, as shown in Fig.1. The pyrolysis process can be divided into four temperature zones. In the first zone $\left(<320^{\circ} \mathrm{C}\right)$, the biomass is dehydrated, and water vapor, carbon dioxide, and volatile organic compounds $\left(\mathrm{CH}_{4}\right)$ are also released. Solid carbon $(\mathrm{C})$ and water decrease while $\mathrm{CH}_{4}$ and $\mathrm{CO}_{2}$ emissions increase. The second zone is $320-560{ }^{\circ} \mathrm{C}, \mathrm{CH}_{4}$ and water content decrease, but $\mathrm{CO}_{2}$ increases. The amount of solid carbon has remained unchanged, but is accompanied with some $\mathrm{H}_{2}$ and $\mathrm{CO}$ appearing. In zone $3\left(560-910{ }^{\circ} \mathrm{C}\right)$, the $\mathrm{CH}_{4}$ content decreases further. The amounts of $\mathrm{H}_{2}$ and $\mathrm{CO}$ increased significantly, but the amounts of other products such as $\mathrm{C}, \mathrm{H}_{2} \mathrm{O}, \mathrm{CO}_{2}$, and $\mathrm{CH}_{4}$ decrease. In the last zone $\left(>910^{\circ} \mathrm{C}\right)$, the pyrolysis is over and almost no reaction occurs. The $\mathrm{H}_{2}$ and $\mathrm{CO}$ contents are highest and remain stable. The carbon residue can be considered as carbon formed by carbonization. The calculated results are in accordance with those of Yan $^{31}$.

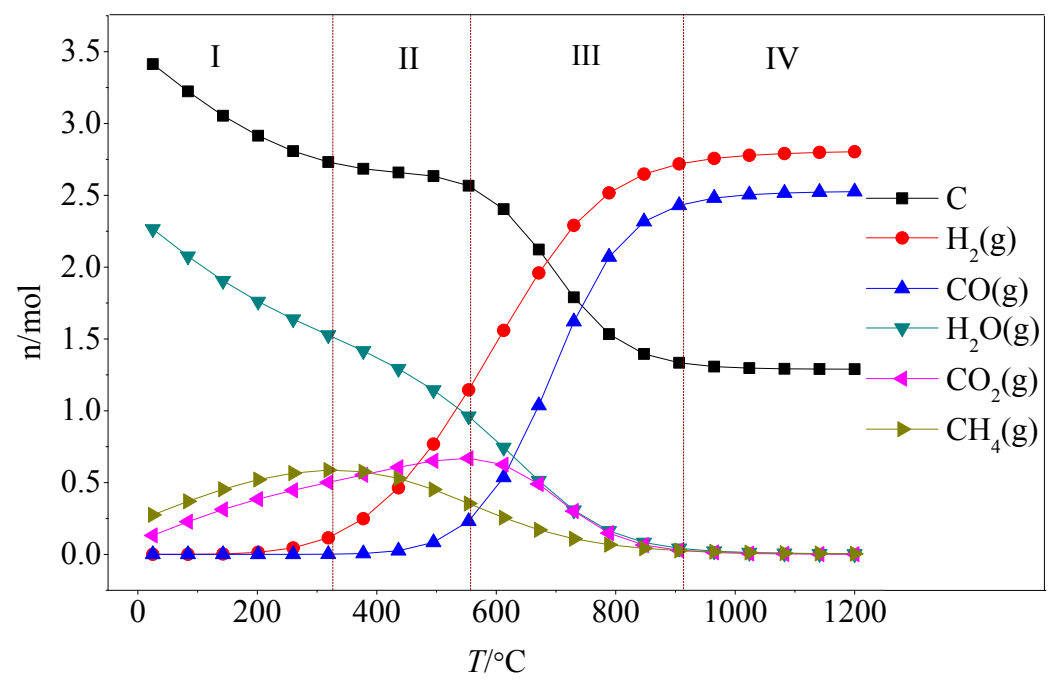

Fig. 1 Effect of temperature on the products of biomass pyrolysis 


\subsubsection{Oxygen gasification process}

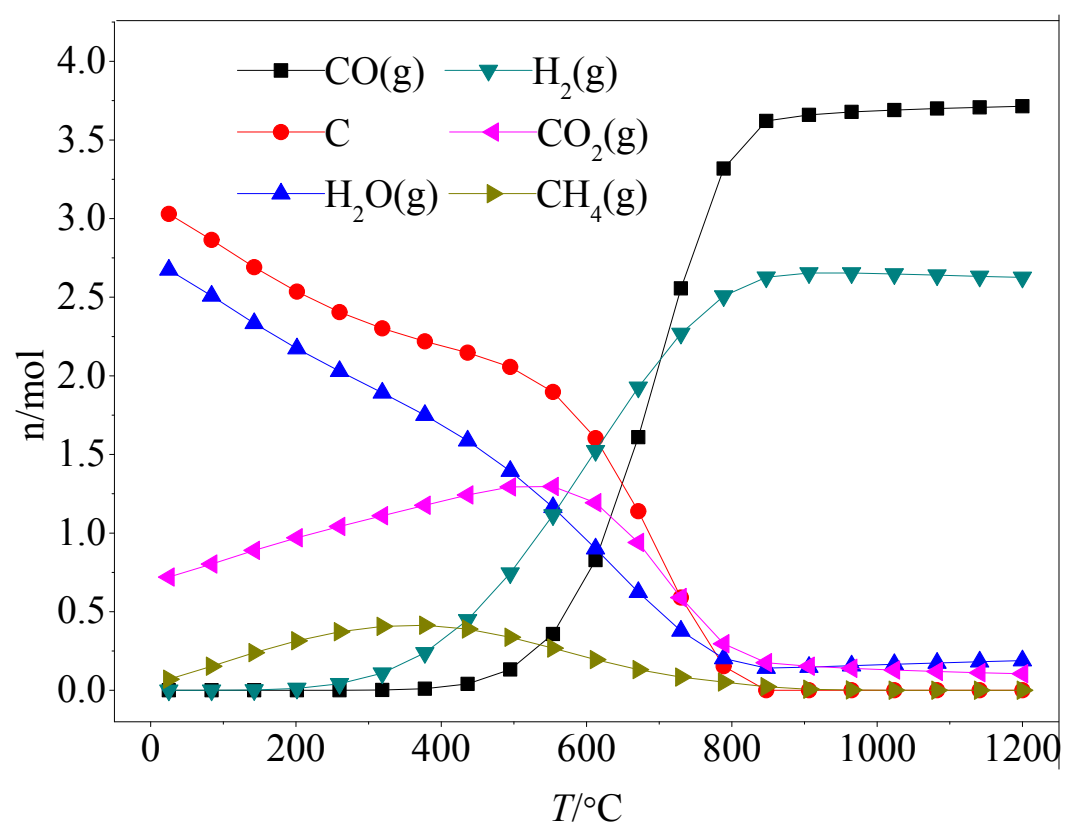

Fig. 2 Effect of temperature on biomass gasification products $(E R=0.2)$

The model in oxygen gasification process is validated by the changes of gasification products at different temperature while the ER is 0.2 , as shown in Fig. 2. It can be seen that the trends of the products of gasification are basically same to that of pyrolysis process, and the biggest difference is that the amount of $\mathrm{CO}(3.5 \mathrm{~mol})$ is higher than that of $\mathrm{H}_{2}(2.5 \mathrm{~mol})$ while the amounts of $\mathrm{CO}$ and $\mathrm{H}_{2}$ produced from pyrolysis process are $2.5 \mathrm{~mol}$ and $2.8 \mathrm{~mol}$, respectively. The addition of oxygen agent is beneficial to promote the formation of $\mathrm{CO}$. The calculated results are in accordance with those of Wang 11.

All these results above show that it is reasonable and reliable to use the Gibbs energy minimization method to simulate the biomass pyrolysis and gasification process based on our proposed HHV prediction model in previous study ${ }^{20}$.

\subsection{Effect of composition in pyrolysis process}

\subsubsection{Effect of C content}

From Fig. 3(a), it can be seen that while the $\mathrm{C}$ content in $1 \mathrm{~mol}$ biomass $(100 \mathrm{~g})$ increases from $35.9 \%$ to $55.9 \%$, the amount of $\mathrm{H}_{2}$ produced from pyrolysis process at high temperature $\left(>700{ }^{\circ} \mathrm{C}\right)$ 
decreases from $3.3 \mathrm{~mol}$ to $2.0 \mathrm{~mol}$. As shown in Fig. 3(b), the amount of $\mathrm{CO}$ is also declined, approximately from $3.0 \mathrm{~mol}$ to $2.0 \mathrm{~mol}$, which is mainly due to the $\mathrm{O} / \mathrm{C}$ molar ratio from 1 to 0.44 while the $\mathrm{C}$ content varies from $35.9 \%$ to $55.9 \%$. The $\mathrm{O} / \mathrm{C}$ molar ratio in carbon monoxide is 1 , it is less likely to generate $\mathrm{CO}$ if the $\mathrm{O} / \mathrm{C}$ molar ratio is lower than 1 . The molar ratio of $\mathrm{H}_{2}$ to $\mathrm{CO}$ decreases firstly and then keeps stable (about 1.1) with increasing temperature in Fig. 3(c). The LHV of syngas increases firstly and then remains unchanged (about $11.65 \mathrm{MJ} \cdot \mathrm{m}^{-3}$ ) in Fig. 3 (d). It should be noted that the molar ratio of $\mathrm{H}_{2}$ to $\mathrm{CO}$ and the LHV are basically the same while the $\mathrm{C}$ content changes, indicating that the $\mathrm{C}$ content exerts the same effect on the amount of $\mathrm{H}_{2}$ and $\mathrm{CO}$ in the gas products. In summary, the increase of $\mathrm{C}$ content is unfavorable for the utilization of syngas as either resource or energy.
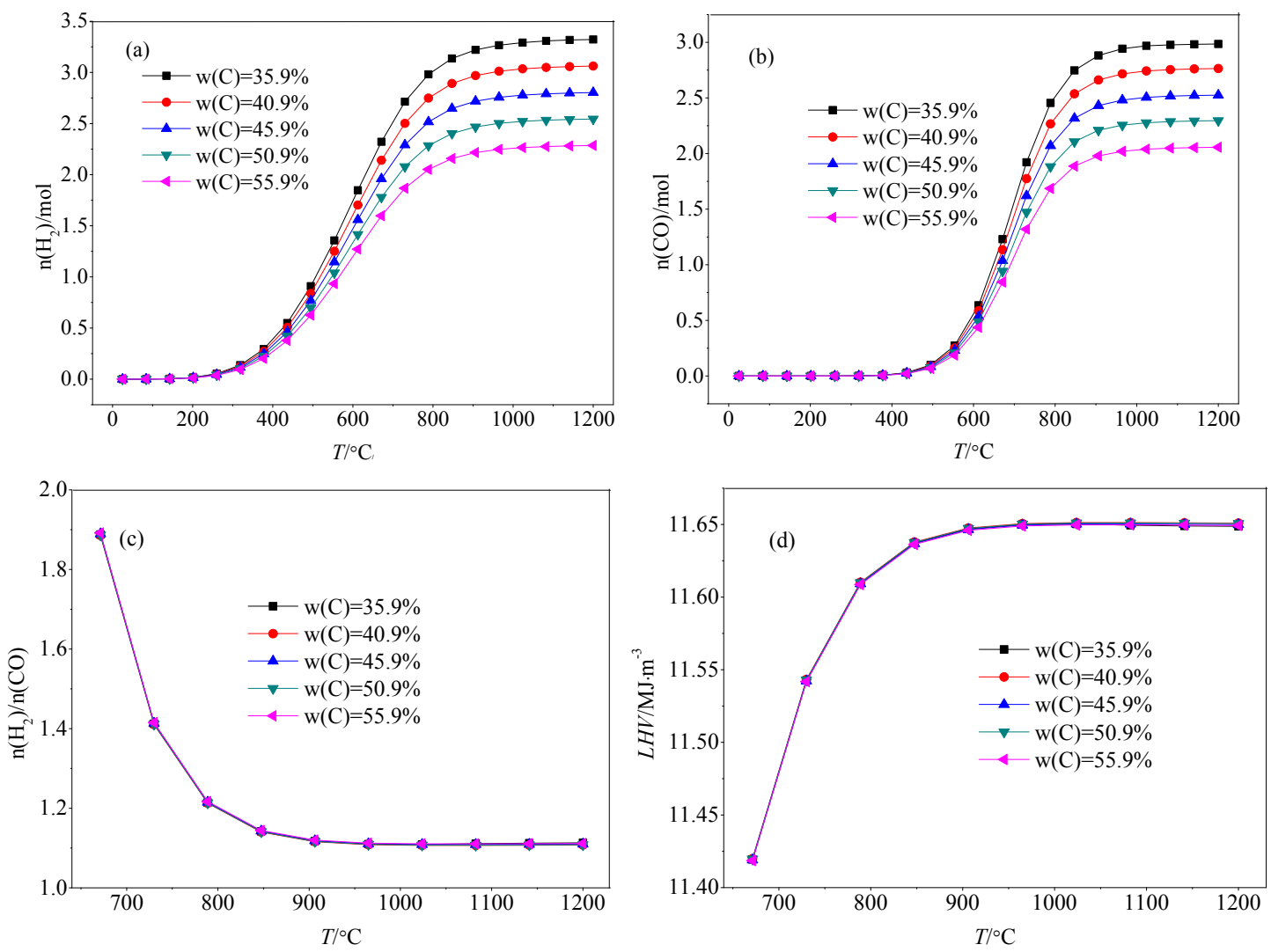

Fig. 3 Effect of $\mathrm{C}$ content on pyrolysis products $\mathrm{H}_{2}, \mathrm{CO}, \mathrm{H}_{2} / \mathrm{CO}$ and $L H V$

\subsubsection{Effect of H content}

As can be seen from Fig. 4(a), when the $\mathrm{H}$ content in 1 mol biomass $(100 \mathrm{~g})$ increases from $2.67 \%$ to $9.67 \%$, the amount of $\mathrm{H}_{2}$ produced from the pyrolysis process at high temperature $\left(>700{ }^{\circ} \mathrm{C}\right)$ increases from $1.0 \mathrm{~mol}$ to $4.7 \mathrm{~mol}$, which is mainly due to the H content growth. However, as shown in Fig. 4(b), the amount of CO remained basically unchanged (around $2.5 \mathrm{~mol}$ ). This is mainly because $\mathrm{O} / \mathrm{C}$ in biomass is maintained at around 0.66. As noted in Fig. 4(c), the molar ratio of $\mathrm{H}_{2}$ and $\mathrm{CO}$ in the gas 

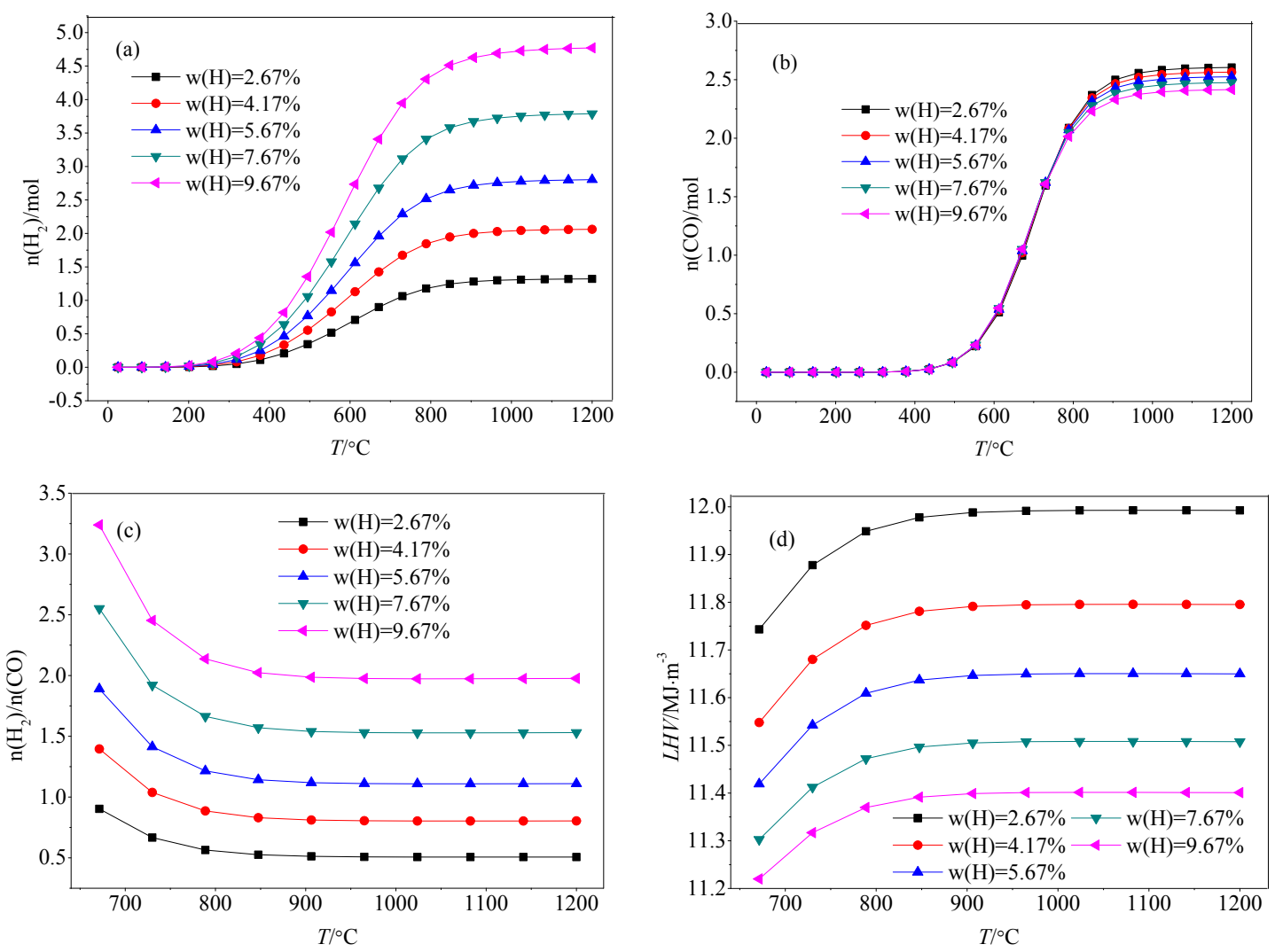

Fig. 4 Effect of $\mathrm{H}$ content on pyrolysis products $\mathrm{H}_{2}, \mathrm{CO}, \mathrm{H}_{2} / \mathrm{CO}$ and $L H V$

\subsubsection{Effect of $O$ content}

From Fig. 5(a), it can be seen that the $\mathrm{O}$ content in 1 mol biomass $(100 \mathrm{~g})$ increases from $30.5 \%$ to $46.5 \%$, and the amount of $\mathrm{H}_{2}$ produced from the pyrolysis process at high temperature $\left(>700{ }^{\circ} \mathrm{C}\right)$ decreases from $3.2 \mathrm{~mol}$ to $2.4 \mathrm{~mol}$. As shown in Fig. 5(b), the mole of CO varies greatly from $1.8 \mathrm{~mol}$ to $2.9 \mathrm{~mol}$, which is mainly due to $\mathrm{O}$ content increasing from $30.5 \%$ to $46.5 \%$, and the values of the $\mathrm{O} / \mathrm{C}$ ratio from 0.45 to 0.85 , which are close to the $\mathrm{O} / \mathrm{C}$ ratio in $\mathrm{CO}$. The molar ratio of $\mathrm{H}_{2}$ to $\mathrm{CO}$ in the gas products decreases continuously, roughly from 1.8 to 0.8 in Fig. 5(c). The reason for the dramatic change is that the amount of $\mathrm{H}_{2}$ decreases while $\mathrm{CO}$ increases during the whole process. And the LHV of the syngas slightly increases, from $11.45 \mathrm{MJ} \cdot \mathrm{m}^{-3}$ to $11.75 \mathrm{MJ} \cdot \mathrm{m}^{-3}$, as shown in Fig. 5(d). In summary, when the $\mathrm{O}$ content is low, syngas with high $\mathrm{H}_{2}$ yield, low $\mathrm{CO}$ yield, high $\mathrm{H} / \mathrm{C}$ ratio and low 
calorific value can be obtained.
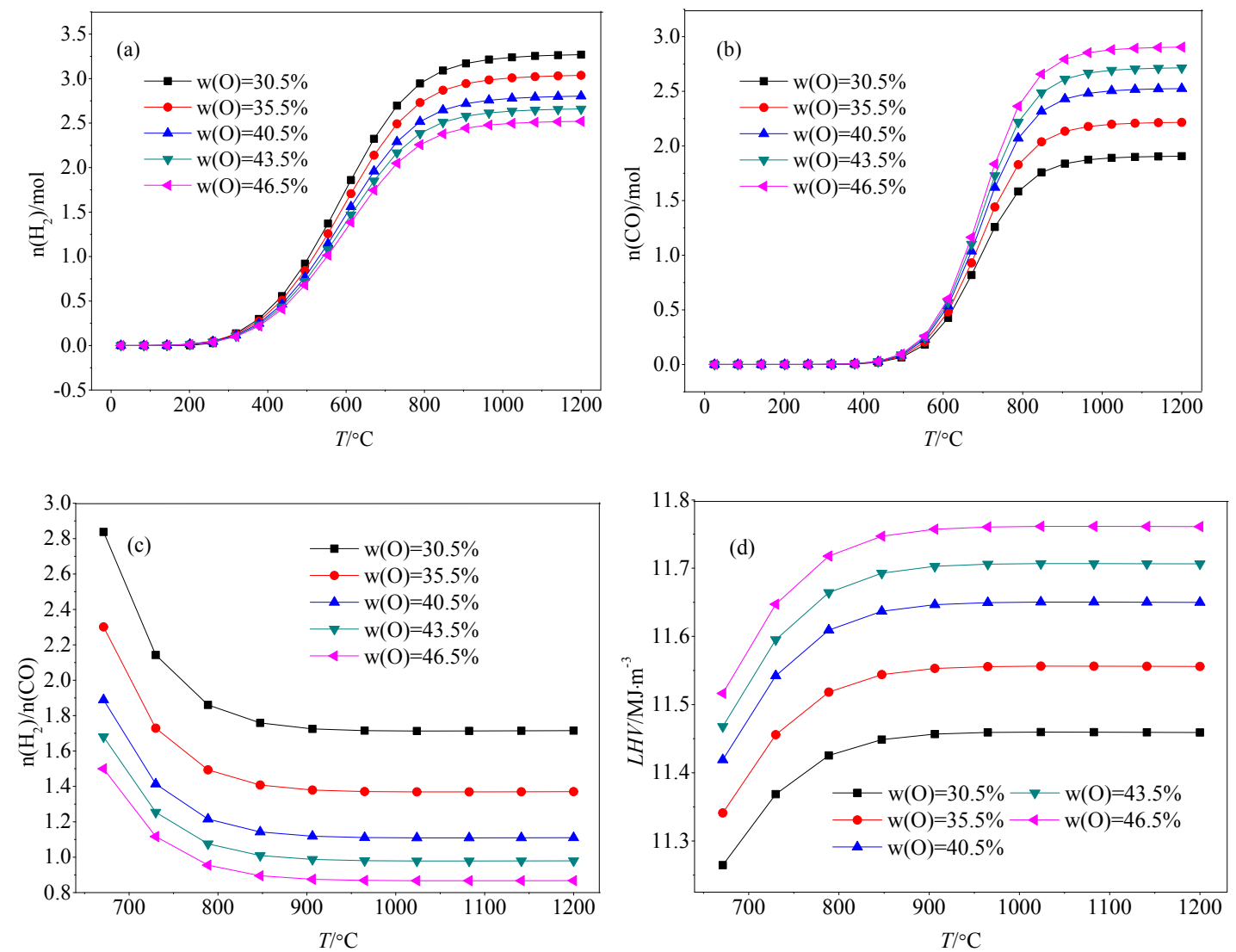

Fig. 5 Effect of oxygen content on pyrolysis products $\mathrm{H}_{2}, \mathrm{CO}, \mathrm{H}_{2} / \mathrm{CO}$ and $L H V$

According to the calculated results of the individual effect of $\mathrm{C}, \mathrm{H}, \mathrm{O}$ contents on the syngas produced by the pyrolysis process of biomass, biomass with high $\mathrm{H}$ content and low $\mathrm{O}$ content is necessary to synthesize a substance with high $\mathrm{H} / \mathrm{C}$ ratio (up to a maximum of 4 ). If syngas is used as an energy source, biomass with high $\mathrm{H}$ and $\mathrm{O}$ contents can be selected as raw material. The increase of $\mathrm{C}$ content has no effect on the $\mathrm{H} / \mathrm{C}$ ratio of syngas and the calorific value, but the yield of products decreases.

\subsection{Effect of composition in oxygen gasification process}

\subsubsection{Determination of ER}

The effect of ER on biomass gasification products at the temperature of $850{ }^{\circ} \mathrm{C}$ is shown in Fig. 6 . It can be seen that when the ER is smaller than 0.2 , there is basically no generation of $\mathrm{CO}_{2}$ and $\mathrm{H}_{2} \mathrm{O}$ produced from the biomass combustion, while the mole of $\mathrm{H}_{2}$ remained basically unchanged at 2.7 mol, and the mole of CO continues to increase, reaches its maximum value of 3.5 mol when ER is 0.2 
and then declines rapidly.

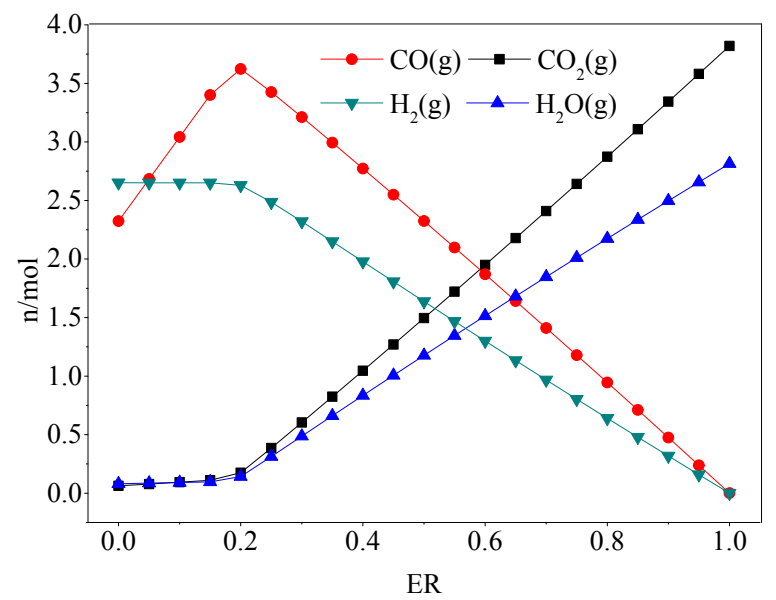

Fig. 6 Effect of ER on biomass gasification products at the temperature of $850{ }^{\circ} \mathrm{C}$

In order to study the effect of different ERs on the resource and energy index of syngas better, the molar ratio of $\mathrm{H}_{2}$ to $\mathrm{CO}$ and the LHV of syngas with the ER at the gasification temperature from 650 to $1150{ }^{\circ} \mathrm{C}$ have been studied, as shown in Fig. 7 (a) and (b). According to Fig. 7 (a), when the ER is less than 0.2 , the molar ratio of $\mathrm{H}_{2} / \mathrm{CO}$ declines rapidly except at $650{ }^{\circ} \mathrm{C}$, and then decreased slowly. According to Fig. 7 (b), the LHV falls off sharply when the ER is greater than 0.2 except $650{ }^{\circ} \mathrm{C}$.
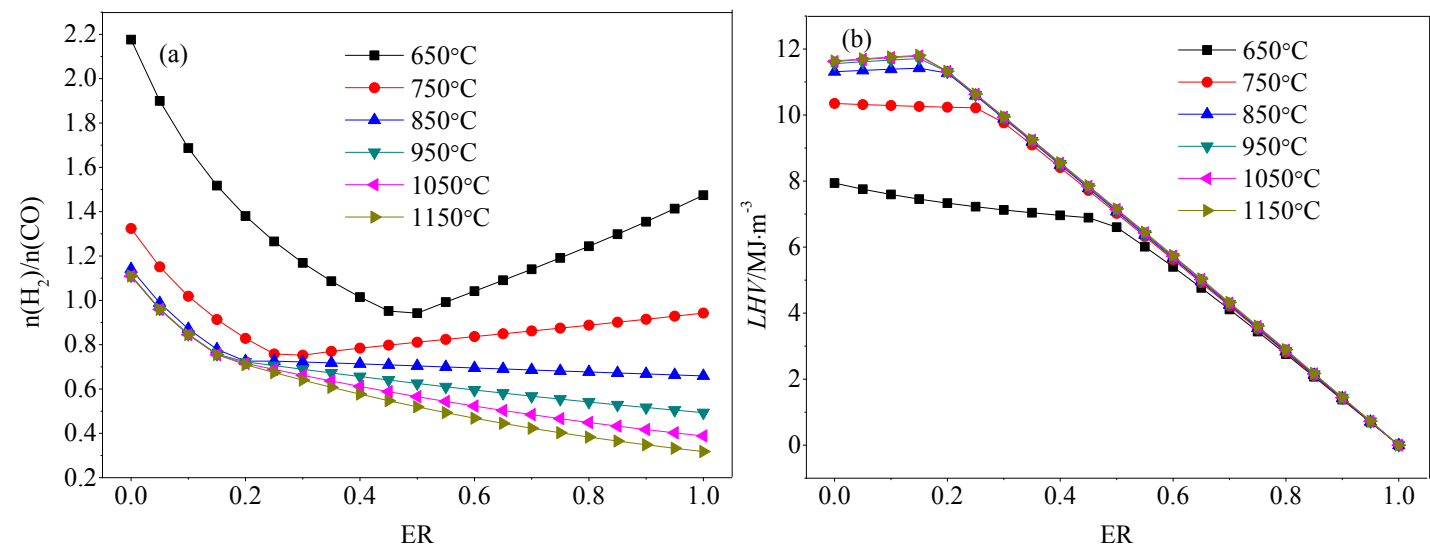

Fig. 7 Effect of ER on biomass gasification products $\left(\mathrm{n}\left(\mathrm{H}_{2}\right)\right.$ and LHV) at different gasification temperatures

The results above prove that the value of ER set at 0.2 is a reasonable gasification equivalence ratio. Therefore, the value of ER in the following calculation is fixed at 0.2.

\subsubsection{Effect of C content}

As can be seen from Fig. 8(a), while the C content in 1 mol biomass (100 g) increases from 35.9\% to $55.9 \%$, the mole of $\mathrm{H}_{2}$ in the gasification products increases at first and then decreases, reaches its maximum value $(2.6 \mathrm{~mol})$ at the $\mathrm{C}$ content of $45.9 \%$. As shown in Fig. $8(\mathrm{~b})$, the mole of CO increases 
continuously (from $2.5 \mathrm{~mol}$ to $4.0 \mathrm{~mol}$ ) and nearly does not change while the C content exceeds $50.9 \%$ and at this time the $\mathrm{CO}$ yield is $94.5 \%$ (the $\mathrm{C}$ content in $1 \mathrm{~mol}$ of raw material is $4.238 \mathrm{~mol}$, so the yield is equal to 4.0/4.238). As shown in Fig. 8(c), the molar ratio of $\mathrm{H}_{2}$ to $\mathrm{CO}$ of the gas products constantly decreased, varying from 1.0 to about 0.6 . The LHV of syngas increases, but the rising trend seems to be smoothed, from $11.65 \mathrm{MJ} \cdot \mathrm{m}^{-3}$ to $11.95 \mathrm{MJ} \cdot \mathrm{m}^{-3}$ in Fig. 8(d). All the results above show that the increase of the $\mathrm{C}$ content is not conducive to the synthesis of substances as resource with a high ratio of $\mathrm{H} / \mathrm{C}$, and it is beneficial to increase the calorific value of syngas when used as energy instead.
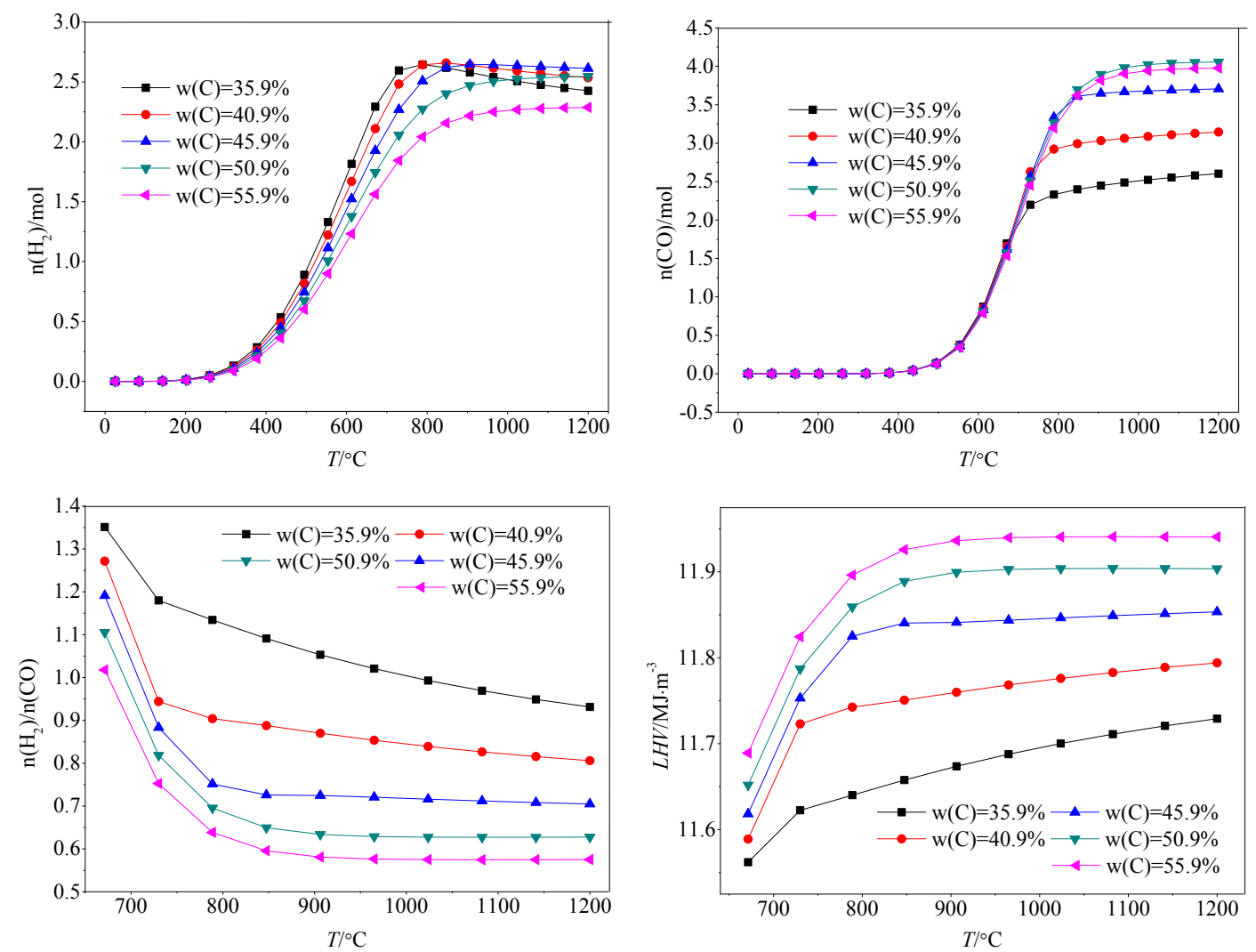

Fig. 8 Effect of carbon content on gasification products $\mathrm{H}_{2}, \mathrm{CO}, \mathrm{H}_{2} / \mathrm{CO}$ and $L H V$

\subsubsection{Effect of H content}

From Fig. 9 (a) and (b), the mole of $\mathrm{H}_{2}$ in the gasification products varies greatly from 1.0 to $4.4 \mathrm{~mol}$ while the $\mathrm{H}$ content of $1 \mathrm{~mol}$ biomass (100 g) increases from $2.67 \%$ to $9.67 \%$. However, the mole of $\mathrm{CO}$ is basically not affected. The molar ratio of $\mathrm{H}_{2}$ to $\mathrm{CO}$ in the gas products continuously increases from 0.35 to 1.3 in Fig. 9(c), which is mainly due to the huge amount of $\mathrm{H}_{2}$ produced. According to Fig. 9 (d), the LHV of syngas greatly reduces from $12.15 \mathrm{MJ} \cdot \mathrm{m}^{-3}$ to $11.55 \mathrm{MJ} \cdot \mathrm{m}^{-3}$. All the results above show that the increase of $\mathrm{H}$ content is beneficial to the synthesis of substances with high $\mathrm{H} / \mathrm{C}$ ratio, while it is not conducive to increase the LHV of syngas. 

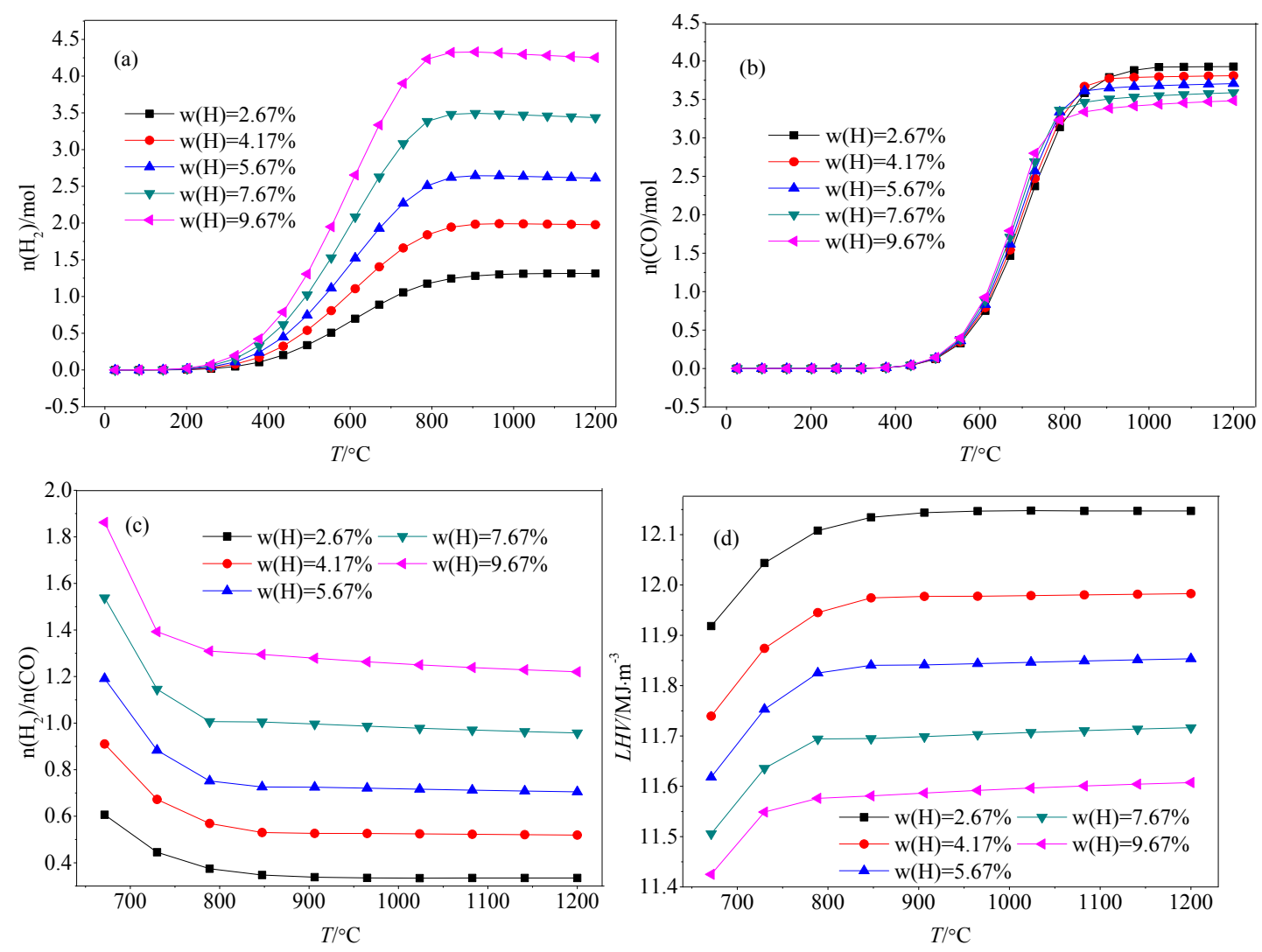

Fig. 9 Effect of hydrogen content on gasification products $\mathrm{H}_{2}, \mathrm{CO}, \mathrm{H}_{2} / \mathrm{CO}$ and $\mathrm{LHV}$

\subsubsection{Effect of $O$ content}

As can be seen from Fig. 10(a) and (b), as the $\mathrm{O}$ content of 1 mol biomass (100 g) increases from $30.5 \%$ to $46.5 \%$, the mole of $\mathrm{H}_{2}$ in the gasification products declines continuously, from 3.3 mol to 1.8 mol. The mole of CO increases first and then decreases, reaching a maximum of 4.0 mol at an oxygen content of $35.5 \%$. As shown in Fig. 10(c), the molar ratio of $\mathrm{H}_{2}$ to $\mathrm{CO}$ in the gas products changes little and stabilizes between $0.7-0.8$. The LHV of the syngas slightly rises from $11.75 \mathrm{MJ} \cdot \mathrm{m}^{-3}$ to 11.85 $\mathrm{MJ} \cdot \mathrm{m}^{-3}$ in Fig. 10(d). All data validate the increase of $\mathrm{O}$ content is neither conducive to the synthesis of substances with high $\mathrm{H} / \mathrm{C}$ ratio, nor effective on the LHV of syngas. 

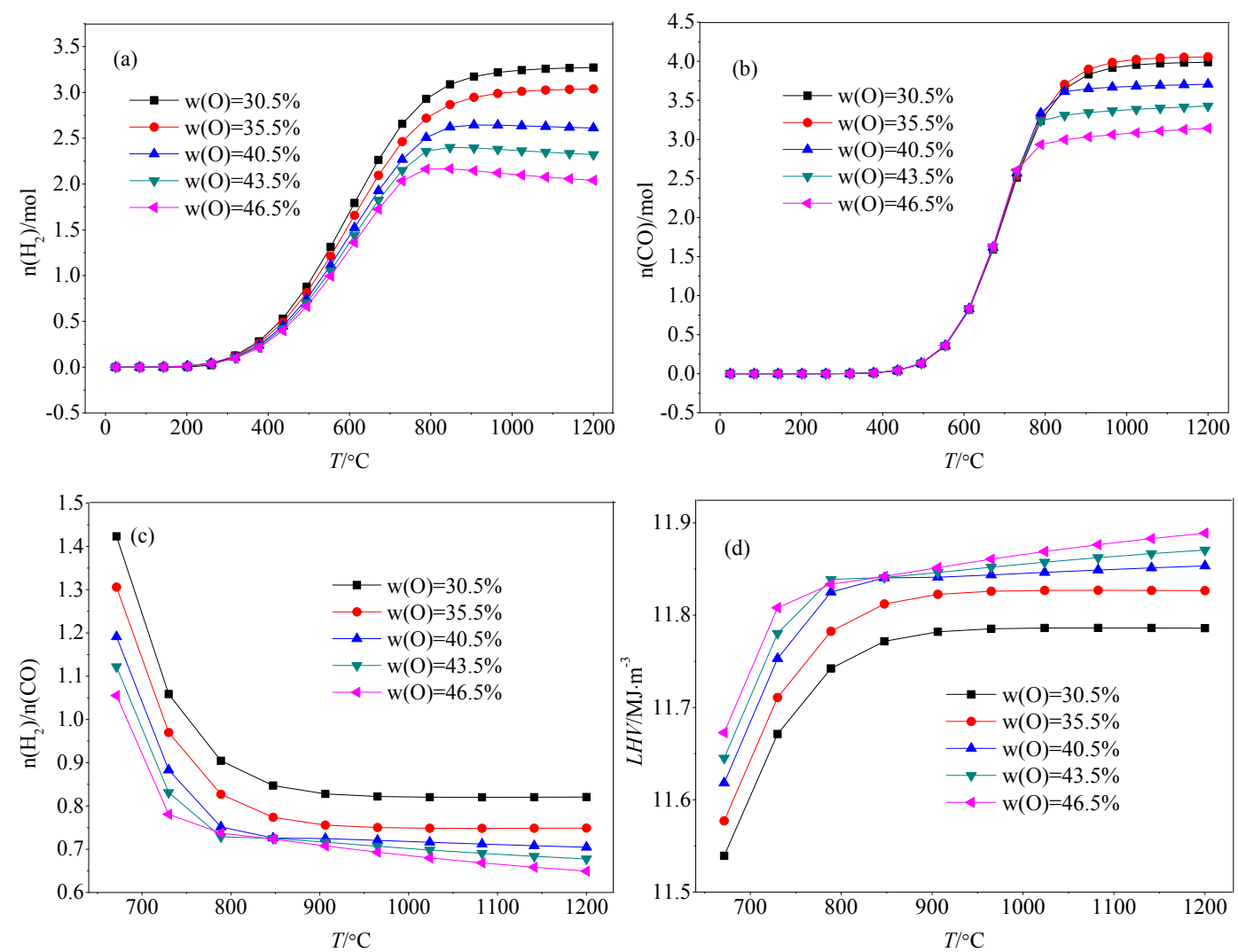

Fig. 10 Effect of oxygen content on gasification products $\mathrm{H}_{2}, \mathrm{CO}, \mathrm{H}_{2} / \mathrm{CO}$ and $L H V$

Based on the calculated results of the effect of $\mathrm{C}, \mathrm{H}, \mathrm{O}$ contents on syngas produced by oxygen gasification process of biomass, biomass with high $\mathrm{H}$ content is appropriate to synthesize a substance with high $\mathrm{H} / \mathrm{C}$ ratio (more than 2). As an energy source, syngas is recommended to be produced by biomass with low $\mathrm{H}$ content.

\section{CONCLUDING REMARKS}

In this study, with the help of Gibbs energy minimization method based on thermochemical data prediction, a method to obtain the relationship between the composition of biomass and the quality of syngas produced has been established successfully. One wheat straw containing near the average elemental composition of 78 types of biomass is selected as the research sample, and the effects of elemental fluctuations have been examined to obtain their effects on the quality of syngas produced from the pyrolysis and gasification process in detail as well as quantitatively. This work gives a quantitative instruction to thermochemical conversion utilization of different composition of varied types of biomass. Moreover, the application scope of this method may be extended to thermochemical conversion utilization of other substances. 


\author{
Nomenclature \\ $C_{p, \mathrm{db}} \quad$ molar heat capacity of dry biomass, $\mathrm{kJ} \cdot \mathrm{mol}^{-1} \cdot \mathrm{K}^{-1}$ \\ $C_{p, \mathrm{O} 2} \quad$ molar heat capacity of oxygen, $\mathrm{kJ} \cdot \mathrm{mol}^{-1} \cdot \mathrm{K}^{-1}$ \\ $G_{T, p}^{t} \quad$ total Gibbs energy of the system, $\mathrm{kJ} \cdot \mathrm{mol}^{-1}$ \\ $H H V \quad$ higher heat value, $\mathrm{kJ} \cdot \mathrm{kg}^{-1}$ \\ LHV lower heat value, $\mathrm{kJ} \cdot \mathrm{m}^{-3}$ \\ $M \quad$ molecular weight of dry biomass, $\mathrm{g} \cdot \mathrm{mol}^{-1}$ \\ $n_{i} \quad$ equilibrium composition is referred to each species, mol \\ $S_{\mathrm{m}}^{o} \quad$ standard molar entropy, $\mathrm{kJ} \cdot \mathrm{mol}^{-1} \cdot \mathrm{K}^{-1}$ \\ $\mathrm{R}$ universal gas constant, $8.314 \times 10^{-3} \mathrm{~kJ} \cdot \mathrm{mol}^{-1} \cdot \mathrm{K}^{-1}$ \\ $\Delta_{\mathrm{f}} H_{\mathrm{m}}^{o} \quad$ standard molar enthalpy of formation, $\mathrm{kJ} \cdot \mathrm{mol}^{-1}$
}

\title{
AUTHOR INFORMATION
}

\section{Corresponding Author}

E-mail: guoxj@shnu.edu.cn (X. J. Guo), hlqian@cpu.edu.cn (H. L. Qian).

\section{Notes}

The authors declare no competing financial interest.

\section{ACKNOWLEDGMENTS}

The authors acknowledge financial support from the National Natural Science Foundation of China (21878337, 21676291) and Jiangsu Agriculture Science and Technology Innovation Fund (JASTIF) (CX(18)3039). 


\section{REFERENCES}

1. Sikarwar, V. S.; Zhao, M.; Clough, P.; Yao, J.; Zhong, X.; Memon, M. Z.; Shah, N.; Anthony, E. J.; Fennell, P. S., An overview of advances in biomass gasification. Energy Environ. Sci. 2016, 9, (10), 2939-2977.

2. Kirubakaran, V.; Sivaramakrishnan, V.; Nalini, R.; Sekar, T.; Premalatha, M.; Subramanian, P., A review on gasification of biomass. Renew. Sust. Energy Rev. 2009, 13, (1), 179-186.

3. Cox, P. M.; Betts, R. A.; Jones, C. D.; Spall, S. A.; Totterdell, I. J., Acceleration of global warming due to carbon-cycle feedbacks in a coupled climate model. Nature 2000, 408, (6809), 184-187.

4. Liu, Q.; Chmely, S. C.; Abdoulmoumine, N., Biomass Treatment Strategies for Thermochemical Conversion. Energy \& Fuels 2017, 31, (4), 3525-3536.

5. Kumar, A.; Jones, D. D.; Hanna, M. A., Thermochemical biomass gasification: a review of the current status of the technology. Energies 2009, 2, (3), 556-581.

6. Karmakar, M.; Datta, A., Generation of hydrogen rich gas through fluidized bed gasification of biomass. Bioresour. Technol. 2011, 102, (2), 1907-1913.

7. Holubar, P.; Zani, L.; Hagar, M.; Fröschl, W.; Radak, Z.; Braun, R., Modelling of anaerobic digestion using self-organizing maps and artificial neural networks. Water Sci. Technol. 2000, 41, (12), 149-156.

8. Mikulandrić, R.; Lončar, D.; Böhning, D.; Böhme, R. In Biomass gasification process modelling approaches, Digital Proceedings of 8th Conference on Sustainable Development of Energy, Water and Environment Systems-SDEWES Conference, 2013; University of Zagreb, Faculty of Mechanical Engineering and Naval Architecture: 2013.

9. Zhang, J.; Toghiani, H.; Mohan, D.; Jr, C. U. P.; Toghiani, R. K., Product Analysis and Thermodynamic Simulations from the Pyrolysis of Several Biomass Feedstocks. Energy \& Fuels 2007, 21, (4), 2373-2385.

10. Zhang, Y.; Zhang, S.; Gossage, J. L.; Lou, H. H.; Benson, T. J., Thermodynamic Analyses of Tr-reforming Reactions To Produce Syngas. Energy \& Fuels 2014, 28, (4), 2717-2726.

11. Wang, K.; Yu, Q.; Qin, Q.; Hou, L.; Duan, W., Thermodynamic analysis of syngas generation from biomass using chemical looping gasification method. Int. J. Hydrogen Energy 2016, 41, (24), 10346-10353.

12. Mendiburu, A. Z.; Carvalho Jr, J. A.; Zanzi, R.; Coronado, C. R.; Silveira, J. L., Thermochemical equilibrium modeling of a biomass downdraft gasifier: Constrained and unconstrained non-stoichiometric models. Energy 2014, 71, (2), 624-637.

13. Pala, L. P. R.; Wang, Q.; Kolb, G.; Hessel, V., Steam gasification of biomass with subsequent syngas adjustment using shift reaction for syngas production: An Aspen Plus model. Renew. Energy 2017, 101, 484-492.

14. Fernandez-Lopez, M.; Pedroche, J.; Valverde, J.; Sanchez-Silva, L., Simulation of the gasification of animal wastes in a dual gasifier using Aspen Plus ${ }^{\circledR}$. Energy Convers. Manage. 2017, 140, (5), 211-217.

15. Han, J.; Liang, Y.; Hu, J.; Qin, L.; Street, J.; Lu, Y.; Yu, F., Modeling downdraft biomass gasification process by restricting chemical reaction equilibrium with Aspen Plus. Energy Convers. Manage. 2017, 153, (6), 641-648.

16. Zhai, M.; Guo, L.; Wang, Y.; Zhang, Y.; Dong, P.; Jin, H., Process simulation of staging pyrolysis and steam gasification for pine sawdust. Int. J. Hydrogen Energy 2016, 41, (47), 21926-21935. 
17. Liu, S.; Chu, L.; Chen, M.; Zhang, W.; Xin, W., Modeling and analysis of the pyrolysis of bio-oil aqueous fraction in a fixed-bed reactor. Fuel 2014, 133, (1), 1-6.

18. Pala, L. P. R.; Wang, Q.; Kolb, G.; Hessel, V., Steam gasification of biomass with subsequent syngas adjustment using shift reaction for syngas production: An Aspen Plus model. Renew. Energy 2017, 101, (11), 484-492.

19. Qian, H.; Zhu, W.; Fan, S.; Liu, C.; Lu, X.; Wang, Z.; Huang, D.; Chen, W., Prediction models for chemical exergy of biomass on dry basis from ultimate analysis using available electron concepts. Energy 2017, 131, 251-258.

20. Qian, H.; Guo, X.; Fan, S.; Hagos, K.; Lu, X.; Liu, C.; Huang, D., A simple prediction model for higher heat value of biomass. J. Chem. Eng. Data 2016, 61, (12), 4039-4045.

21. Qian, H.; Zhu, W.; Liu, C.; Lu, X.; Georgios, K.; Rafiqul, G., Exergy efficiency based design and analysis of utilization pathways of biomasses. In Computer Aided Chemical Engineering, Elsevier: 2018; Vol. 43, pp 857-862.

22. Qian, H.; Chen, W.; Zhu, W.; Liu, C.; Lu, X.; Guo, X.; Huang, D.; Liang, X.; Kontogeorgis, G. M., Simulation and evaluation of utilization pathways of biomasses based on thermodynamic data prediction. Energy 2019, 173, 610-625.

23. Lwin, Y., Chemical equilibrium by Gibbs energy minimization on spreadsheets. Int. J. Eng. Educ. 2000, 16, (4), 335-339.

24. Shabbar, S.; Janajreh, I., Thermodynamic equilibrium analysis of coal gasification using Gibbs energy minimization method. Energy Convers. Manage. 2013, 65, (3), 755-763.

25. Barin, I.; Platzki, G., Thermochemical data of pure substances. Wiley Online Library: 1989; Vol. 304.

26. Song, G.; Shen, L.; Xiao, J., Estimating specific chemical exergy of biomass from basic analysis data. Ind. Eng. Chem. Res. 2011, 50, (16), 9758-9766.

27. Rath, J.; Wolfinger, M.; Steiner, G.; Krammer, G.; Barontini, F.; Cozzani, V., Heat of wood pyrolysis. Fuel 2003, 82, (1), 81-91.

28. Champion, W. M.; Cooper, C. D.; Mackie, K. R.; Cairney, P., Development of a chemical kinetic model for a biosolids fluidized-bed gasifier and the effects of operating parameters on syngas quality. Journal of the Air \& Waste Management Association 2014, 64, (2), 160-174.

29. Mohammed, M.; Salmiaton, A.; Azlina, W. W.; Amran, M. M.; Fakhru'l-Razi, A., Air gasification of empty fruit bunch for hydrogen-rich gas production in a fluidized-bed reactor. Energy Convers. Manage. 2011, 52, (2), 1555-1561.

30. Vassilev, S. V.; Baxter, D.; Andersen, L. K.; Vassileva, C. G., An overview of the chemical composition of biomass. Fuel 2010, 89, (5), 913-933.

31. Yan, R.; Yang, H.; Chin, T.; Liang, D. T.; Chen, H.; Zheng, C., Influence of temperature on the distribution of gaseous products from pyrolyzing palm oil wastes. Combustion and Flame 2005, 142 , (1-2), 24-32. 